\title{
Islamic Branding and Social Media: Implications on Stay Decisions in Sharia Hotel (Survey on Guest Staying at Noor Hotel: Moeslim Boutique Hotel Bandung)
}

\section{Debi D. Andini, Moch. Adib Sultan, Neni Sri Wulandari, and Mira Nurfitriya}

Economics and Islamic Finance Department, Universitas Pendidikan Indonesia, Jl. Dr. Setiabudhi No. 229 Kota Bandung

\section{Abstract}

Public awareness of Moslem-friendly tourism is increasing but it has not been followed by supporting facilities such as places of worship, halal food and beverages, also sharia hotel. On the other hand, the growth of moslem tourist visiting in 2014 was 30\% to $40 \%$ higher than the growth of conventional tourists who come to Indonesia but had not been matched by the availability of adequate sharia hotels. This research uses

Corresponding Author: Debi D. Andini

debideandini@gmail.com

Received: 10 February 2019

Accepted: 14 March 2019

Published: 28 March 2019

Publishing services provided by

Knowledge E

(c) Debi D. Andini et al. This article is distributed under the terms of the Creative Commons

Attribution License, which

permits unrestricted use and

redistribution provided that the

original author and source are credited.

Selection and Peer-review under the responsibility of the ICIEBP Conference Committee. primary data through online questionnaire distribution on one of social media platforms called instagram. The population in this research are the guests who stay in Noor Hotel Bandung with samples of 100 respondents with purposive sampling technique. The method used in this reasearch is descriptive verivicative with multiple linear regression test equipment. The results show that Islamic branding is in the highest category and social media is in medium category. While on multiple regression test, islamic branding and social media have a significant positive effect to the decision to stay at Noor Hotel. R square value of 0.492 or $49.2 \%$ means that the decision to stay at Noor Hotel is influenced by Islamic Branding and social media by $49 \%$, while the rest $51 \%$ is influenced by other factors not examined by the author.

Keywords: Sharia Hotel, Islamic Branding, Social Media, Stay Decision, Noor Hotel.

\section{Introduction}

In 2014, Chairman of AHSIN (Association of Indonesian Sharia Hotels and Restaurants), Sofyan, revealed that the growth of Muslim tourist visits to Indonesia was around 30 to 40 percent. The number of Muslim tourist visits is higher than the growth in the number of conventional tourists (Fatimah, 2015).

This is an opportunity for Indonesia to improve halal tourism facilities to be even better, for example by increasing the number of sharia hotels in various regions, considering the number of sharia hotels currently available is still minimal compared to conventional 
hotels, while public awareness of Muslim tourist friendly tourism is getting higher (Micom, 2016).

Today, in addition to being aware of halal products such as food and cosmetics, the awareness of the Moslem community in choosing a place to stay has begun to grow. Middle-class and upper-class Moslems begin to look for hotels that provide peace to worship, namely the availability of a place of worship, an environment that provides an Islamic atmosphere and food in the restaurant that is guaranteed to be halal (Widyarini, 2014).

This business opportunity is also captured by hoteliers in establishing sharia hotels. Sharia hotels in the city of Bandung include: Lingga Hotel, Ruby Sharia Hotel, Narapati Indah Syariah Hotel and Convention, Cinnamon Sharia Boutique Hotel and Noor Hotel: Moslem Boutique Hotel.

Noor Hotel can be called the pioneer of Moslem boutique hotel in Bandung (Chan, Purbasari, \& Tresna, 2017). This hotel is also one of the sharia hotels whose occupancy rates are almost always above $50 \%$.

Following is the percentage of occupancy rates at Noor Hotel:

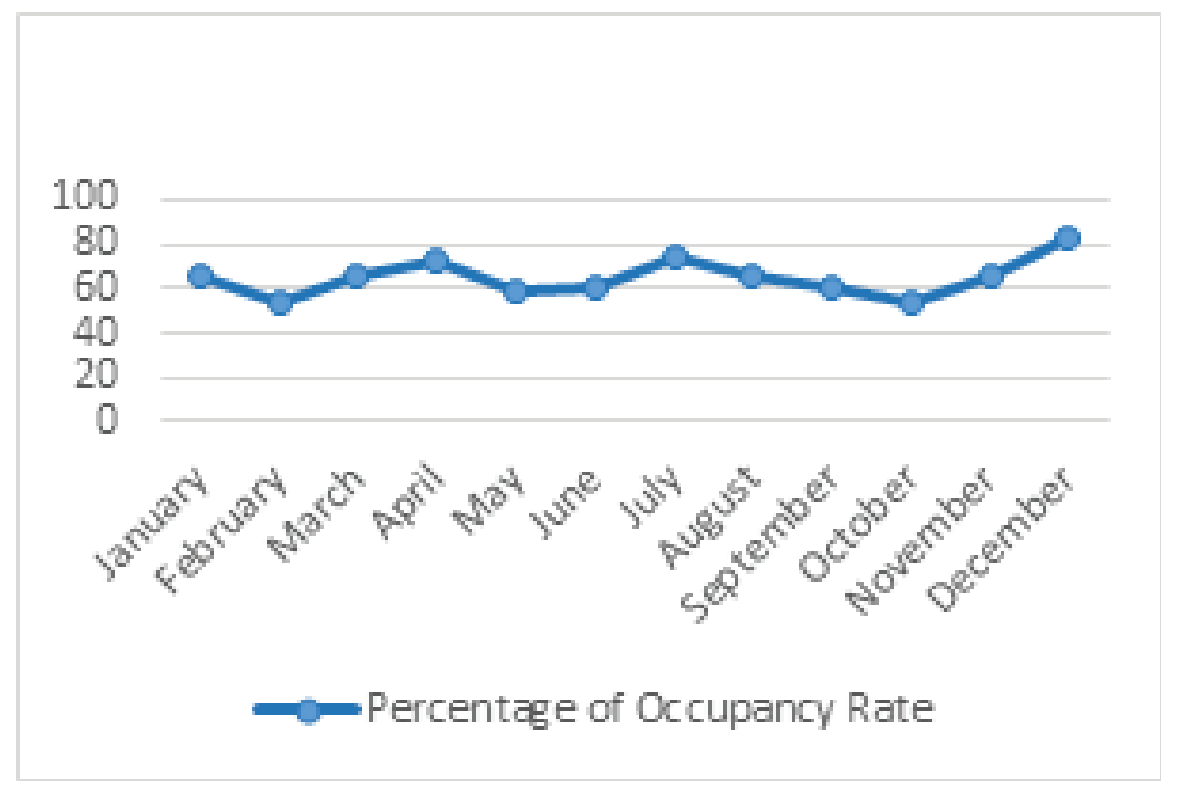

Figure 1: Percentage of Noor Hotel Occupancy Rate in 2017.

The fact that the room occupancy rate is almost always above $50 \%$, the authors are interested in pre-researching 30 guests related to the things that made them to decide to stay at Noor Hotel:

Based on the results of the pre-study, the reason for guests interested in staying at Noor Hotel is dominated by Islamic nuances or Islamic interior by $70 \%$, the second place is dominated by the influence of social media, especially Instagram. The guests were 
TABLE 1: Factors that make guests interested to stay.

\begin{tabular}{|l|l|c|c|} 
No. & Factors & respondent & Percentage \\
\hline $\mathbf{1}$ & Islamic Atmosphere & 21 & $70 \%$ \\
\hline $\mathbf{2}$ & Instagramable & 4 & $13,3 \%$ \\
\hline $\mathbf{3}$ & Location & 3 & $10 \%$ \\
$\mathbf{4}$ & etc & 2 & $6,7 \%$ \\
\hline Source: Pre Research (2017) & & \\
\hline
\end{tabular}

curious about the Islamic interior decoration that gave a warm and homey impression. No wonder this hotel has a high occupancy rate every month and has won the award as the "Best Guest Experience" hotel at the 2017 Traveloka Awards (Rosadi, 2017)

Alserhan (2010) mentioning to be able to say that a product have an islamic branding is when the product is in accordance with Islamic Sharia, originates or is in an Islamic State and the target market targeted by products is muslim consumers

According to Philip Kotler and Kevin Lane Keller (2015) social media is a media used by consumers to share text, images, sound and video information both with other people and companies or vice versa.

To justify that social media and Islamic branding are factors that can influence the decisions to stay at a sharia hotel, this study tries to confirm several previous studies including the results of research conducted by Widyarini (2014), social media especially facebook and websites have a positive and significant effect towards the decision to stay at a sharia hotel. The better and more interesting content created on Facebook and the website, the more attracted customers will come.

Nasrullah (2015) conducted a study and concluded that Islamic branding has a significant influence on consumer decisions, especially among Moslems who are knowledgeable and intellectual where Islam has become a way of life. Islamic branding which is intended not only as a brand name of its product describes Islam but also seen from the production process or other operational activities must be considered so that it is in accordance with Islamic values.

Using social media to provide information, influenced and stimulated Moslem consumers makes Noor Hotel experiences an increase in sales as well as getting awards that can improve its good image in the eyes of consumers. In addition, Noor Hotel also makes Islamic-based lodging services, from services to interior design with eastern themes. The middle factor is able to attract the interest of both Muslim and non-Muslim people to stay at Noor Hotels. Therefore, this study intends to examine "Islamic Branding 
and Social Media: Implications for Decisions to Stay in Sharia Hotels (Survey on Guests Staying at Noor Hotels: Moslem Boutique Hotel Bandung)".

\section{Literature Review}

A Muslim traveler who is traveling must act according to the pillars of Islam and the pillars of faith. Otherwise it is considered a sin. Islam is a way of life, therefore a Muslim is required to perform the religious duties wherever they are (Begg, 1997).

For example, a Muslim tourist must always pray five times a day and could always consume halal food and drinks as the command of Allah in the following Qur'an to eat halal food:

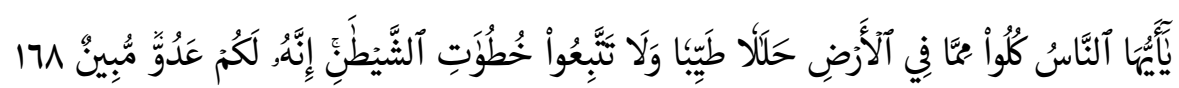

Meaning: "O men! Eat the lawful and good things out of what is in the earth, and don't follow the footsteps of the Shaitan; surely he is your open enemy" (QS. Al-Baqarah: 168

For this reason, this is a concern for hotel business owners to provide facilities such as the availability of halal food and drinks, the Qibla direction, mukena, prayer mats, the Qur'an and information to prayer time so that Muslim tourists can still perform their religious duties (N.H Hashim, 2006). In the view of some experts, the analysis of religious need is vital in providing hotel services and designing a marketing strategy.

At the moment, this approach is known as Islamic branding, where products are marketed according to the needs of Moslem consumers physically and spiritually, where producers or service providers pay attention to the compliances including the halal production process and it pays attention to the needs of Moslem consumers (Aoun \& Tournois, 2015).

Nasrullah (2015) conducted a study and concluded that Islamic branding has a significant influence on consumer decisions, especially among Moslems who are knowledgeable and intellectual where Islam has become a way of life. Islamic branding intended not only as a brand name of its product that describes Islam but also seen from the production process or other operational activities must be considered so that it is in accordance with Islamic values.

Using the Islamic branding strategy at Noor Hotel does not necessarily immediately raise the name of Noor Hotel but this hotel also conducts vigorous promotions through social media.

Instagram is one of the most widely used social media by Indonesian people. About 45 million Indonesians actively use this social media. Susan Rose, Product Marketing 
Director of Instagram, sees this as an opportunity that brands can use to get closer to their customers. Business adoption through Instagram in Indonesia is among the top five in the world (Santosa, 2017).

Based on research conducted by Widyarini (2014), social media especially Facebook and the website have a positive and significant effect on the decision to stay in sharia hotels. The better and more interesting contents created on Facebook and the website, the more attracted customers will come.

\section{Methodology}

This research using descriptive verivicative method because this study tries to describe the value of independent variables without comparing or connecting with other variables. The verification method in this study aims to describe the truth of the influence of Islamic branding and social media on the decisions of guests staying at Noor Hotel Bandung.

The object of this research is the variables involved. They are Islamic Branding and Social Media as independent variables and Decision to Stay as dependent variable. The subjects in this research is the guests who stay in Noor Hotel Bandung with a population of 7648 people. Sampling techniques using a purposive sampling approach quota sampling obtained 100 respondents.

The sample requirement in this study is the guest who ever stayed at Noor Hotel. Moreover, the author choosing samples is by examining the Noor Hotel Instagram account, sending DM (direct massage) to the accounts that posted their photos while in Noor Hotel's room and tagging Noor Hotel's account in the photo. If they are willing to fill out the questionnaire, the author will send a questionnaire link in the form of google form to the respondents.

\section{Result}

Based on the results of research in the field, it is discovered that general description of the characteristics of respondents are as follows:

Based on the graph above, information can be obtained about the age of respondents. The highest respondents were in the age range of $26-30$ years as many as $46 \%$ or 46 people, while respondents who were aged over 40 years are 5 people or $5 \%$ of 
TABLE 2: Characteristics of Respondents by age.

\begin{tabular}{l|c|c|c|} 
No. & Age & $\begin{array}{c}\text { Frequency } \\
\text { (person) }\end{array}$ & Frequency (\%) \\
\hline 1 & $20-25$ & 16 & $16 \%$ \\
\hline 2 & $26-30$ & 46 & $46 \%$ \\
\hline 3 & $31-35$ & 22 & $22 \%$ \\
\hline 4 & $36-40$ & 11 & $11 \%$ \\
\hline 5 & $>40$ & 5 & $5 \%$ \\
\hline & Total & 100 person & $100 \%$ \\
\hline
\end{tabular}

the total respondents. This shows that respondents who stay the most at Noor Hotel are in the productive age range of 26-30 years.

TABLE 3: Characteristics of Respondents by Education.

\begin{tabular}{l|c|c|c|} 
No. & Education & $\begin{array}{c}\text { Frequency } \\
\text { (person) }\end{array}$ & Frequency (\%) \\
\hline 1 & SMA & 8 & $8 \%$ \\
\hline 2 & D3 & 12 & $12 \%$ \\
\hline 3 & S1 & 66 & $66 \%$ \\
\hline 4 & S2 & 14 & $14 \%$ \\
\hline & Total & 100 person & $100 \%$ \\
\hline
\end{tabular}

The graph above shows that the highest respondent's education level was in the S1 education in the number of 66 people or $76 \%$, while high school level respondents were 8 people. This shows that the majority of guests who have stayed at Noor Hotels have an S1 education background.

TABLE 4: Characteristics of Respondents by Income.

\begin{tabular}{|c|c|c|c|}
\hline No. & Income & $\begin{array}{c}\text { Frequency } \\
\text { (person) }\end{array}$ & Frequency (\%) \\
\hline 1 & $0-1.000 .000$ & 14 & $14 \%$ \\
\hline 2 & $1.000 .001-5.000 .000$ & 49 & $49 \%$ \\
\hline 3 & $5.000 .001-10.000 .000$ & 22 & $22 \%$ \\
\hline 4 & $10.000 .001-15.000 .000$ & 2 & $2 \%$ \\
\hline & Total & 100 person & $100 \%$ \\
\hline
\end{tabular}


The graph above shows the monthly income per respondent. Most respondents are in the income range of $1,000,001-5,000,000$, as many as $49 \%$ or 49 people while the respondents are at least in the income range $>15,000,000$, namely 2 respondents or $2 \%$ from the total of all respondents. This shows that in the range of income, people who stay at Noor Hotel are those who have middle to upper economic level.

\subsection{Descriptive analysis}

Based on the results of a survey conducted by respondents, respondents' responses to the Islamic Branding variable get an average score of $88.67 \%$ where the value is included in the very good category. Respondents' responses to social media variables get an average score of $82.64 \%$ where the value is included in the very good category. In addition, the respondent's response to the decision decision variable was $88.65 \%$ where the value was also included in the very good category.

\subsection{Classic assumption test}

\subsubsection{Normality test}

This research using the Kolmogorov Smirnov method. In this study the variables used are stated to be normally distributed. With the basis of decision making as follows:

Ho: the data is normally distributed

H1: data is not normally distributed

If the probability (sig value) $>0.05$ then Ho is accepted

If the probability is (sig value) $<0.05$ then Ho is rejected.

This can be seen from the results of calculations using SPSS that the probability value is at $0.200>0.05$ then $\mathrm{HO}$ is accepted and it can be said that the instrument has a residual value that is normally distributed.

\subsubsection{Multicollinearity test}

From the results of the multicollinearity test it can be concluded that VIF is at the number $1.438<10$ so it can be said that the instrument does not occur multicollinearity. 


\subsubsection{Heterocedacity test}

Based on the results of the heterocedacity test it can be concluded that the probability value is at the number $0.427>0.05$ and $0.693>0.05$ then $\mathrm{Ho}$ is accepted, so it can be said that the instrument does not occur heteroskedasitas.

\subsection{Multiple regression analysis}

TABLE 5: Multiple Regression Analysis.

\begin{tabular}{|c|c|c|c|c|c|c|}
\hline \multicolumn{7}{|c|}{ Coefficients } \\
\hline \multicolumn{2}{|c|}{ Model } & \multicolumn{2}{|c|}{ Unst Coefficients } & St. Coef & $\mathrm{T}$ & Sig \\
\hline & & $B$ & Std error & Beta & & \\
\hline \multirow[t]{3}{*}{1} & (constant) & 11.785 & 4.875 & & 2.417 & 0.017 \\
\hline & Islamic branding & 0.374 & 0.100 & 0.324 & 3.732 & 0.000 \\
\hline & Social Media & 0.435 & 0.081 & 0.468 & 5.396 & 0.000 \\
\hline
\end{tabular}

Based on the results of the multiple regression test above, the regression equation is obtained as follows:

$$
\mathrm{Y}=11,78+0,37 \mathrm{IB}+0,44 \mathrm{MS}
$$

The regression equation above has the following meanings:

1. $\beta O=$ constant $=11.78$, meaning that if the Islamic Branding and Social Media variable does not change, then the rate of stay decision is at $11.78 \%$.

2. $\beta 1=$ Islamic Branding coefficient $=0.37$, meaning that when Islamic Branding increases by $1 \%$, the decision to stay increases by $0.37 \%$.

3. $\beta 2=$ Social Media coefficient $=0.44$, meaning that when Social Media effectiveness increases by $1 \%$, the decision to stay increases by $0.44 \%$.

\subsection{Hypothesis T test}

Based on the results of the hypothesis testing, it can be explained for each variable as follows: 
TABLE 6: Result of Hypothesis T Test (Partial Test).

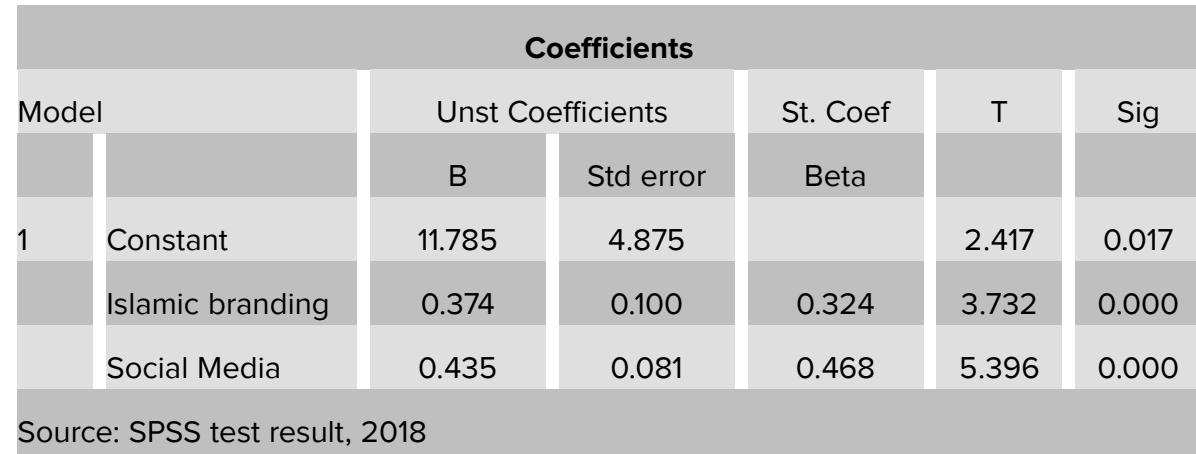

\subsubsection{Islamic branding}

The results of the $t$ test obtained the value of $t$ count variable is the Islamic branding is 3.732 compared to the value of $t$ table of 1.66 , it can be concluded that $t$ count is greater than $\mathrm{t}$ table then $\mathrm{Ho}$ is rejected and $\mathrm{H} 1$ is accepted. This means that Islamic branding has a significant partial effect on the decision to stay.

\subsubsection{Social media}

The results of the t test obtained the tcount of the Islamic branding variable is 5.396 compared to the ttable value of 1.66 , it can be concluded that $t$ count is greater than $\mathrm{t}$ table then $\mathrm{Ho}$ is rejected and $\mathrm{H} 1$ is accepted. This means that social media has a significant partial effect on the decision to stay.

\subsection{Hypothesis F test}

TABLE 7: Result of Hypothesis F Test (Simultaneous Test).

\begin{tabular}{|c|c|c|c|c|c|}
\hline F count & F table & Sig & R-Squared & Decision & Note \\
\hline 46.932 & 3.94 & 0.0000 & 0.492 & Accept $\mathrm{H}_{1}$ & Significant \\
\hline
\end{tabular}

Based on the table above it can be seen that Fcount $=46.932$ so that it meets the criteria that $\mathrm{H} 1$ is accepted if Fcount 46.93260> Ftable 3.94 with sig $(0.000)<0.05$. This shows that Islamic branding and social media have a positive and significant effect simultaneously on the decision to stay. 


\subsection{Analysis of coefficient determination}

TABLE 8: Result of Coefficient Determination Analysis.

\begin{tabular}{|c|c|c|c|c|}
\hline \multicolumn{5}{|c|}{ Model Summary } \\
\hline Model & $\mathrm{R}$ & R Square & $\begin{array}{l}\text { Adjusted R } \\
\text { Square }\end{array}$ & Std. Error \\
\hline 1 & $0.701^{a}$ & 0.492 & 0.481 & 4.530 \\
\hline
\end{tabular}

Based on the results of table 7 obtained $R^{2}$ value of 0.492 , meaning that the contribution of the independent variable to the dependent variable is $49.2 \%$ and the remaining $50.8 \%$ is influenced by other factors outside the research.

\section{Conclusion}

The total number of independent variables namely Islamic Branding and Social Media simultaneously have a significant effect on the dependent variable, namely the decision to stay. This is because Noor Hotel provides worship facilities that make it easier for Muslims to worship, but also because the hotel atmosphere is Islamic and comfortable to live in is a reason for guests to decide to stay at Noor Hotel. Social Media also has a significant role in helping Noor Hotels in marketing their lodging services, as evidenced by the majority of respondents who were asked about the first time sources knew Noor Hotel was from Instagram social media.

[1] Alserhan, A. B. (2010). On Islamic Branding : Brands as Good Deeds. Journal of Islamic Marketing Vol 1. No. 2, 101-106.

[2] Aoun, I., \& Tournois, L. (2015). Building Holistic Brands : an Exploratory study of Halal Cosmetics. Journal of Is/amic Marketing 6(1), 109-132.

[3] Begg, M. (1997). Islam and Travelling. Diambil kembali dari http://www.islamiccentre. org

[4] Chan, A., Purbasari, R., \& Tresna, P. W. (2017). Sharia Marketing Analysis in Noor Hotel Bandung. Parahyangan International 3rd Accounting \& Business Conference 2017, (hal. 1). Bandung.

[5] Chan, A., Purbasari, R., \& Tresna, P. W. (2017). Sharia Marketing Analysis in Noor Hotel Bandung. Parahyangan International Accounting and Business Conference . 
[6] Fatimah, N. (2015). Pengaruh Bauran Pemasaran Jasa Terhadap Nilai dan Niat Berperilaku Pelanggan Hotel Syariah Grand Kalimas di Surabaya. . Jurnal Ekonomi dan Bisnis Vol. 1, No. 2.

[7] Kotler, P., \& Keller, K. L. (2015). Manajemen Pemasaran. Jakarta: Erlangga.

[8] Micom. (2016, Agustus 25). Indonesia Berpotensi Menjadi Wisata Halal Paling Unggul. . Diambil kembali dari mediaindonesia.com: http://www.mediaindonesia. com/news/read/63536/indonesia-berpotensi-jadi-destinasi-wisata-halal-palingunggul/2016-08-25

[9] N.H Hashim, J. M. (2006). Tourism and Islam : Understanding and embracing opportunities. From the Experts.

[10] Nasrullah, M. (2015). Islamic Branding, Religiusitas dan Keputusan Konsumen Terhadap Produk. . Jurnal Hukum Islam 13(79), 79-87.

[11] Rosadi, D. (2017, April 5). 28 Hotel di Jabar Raih Penghargaan Traveloka Awards . Diambil kembali dari merdeka.com: https://bandung.merdeka.com/lapak/28-hoteldi-jabar-raih-penghargaan-traveloka-hotel-awards-2017-170405k.html

[12] Santosa, I. (2017, December 21). Peluang Bisnis dari Media Sosial. Jakarta.

[13] Widyarini. (2014). Variabel yang Mempengaruhi Keputusan Pemilihan Hotel Syariah. Jurnal Ekonomi dan Bisnis Islam Vol. IX, No.1 ISSN:1907-9109. 